\title{
Development of Health Resort Casino System in Integrative Medicine
}

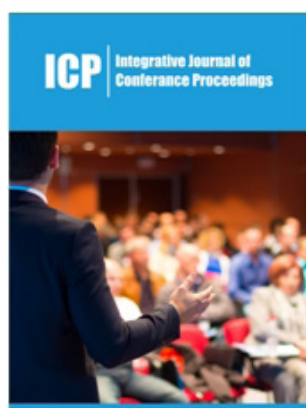

*Corresponding author: Hiroshi Bando, Medical Research, Nakashowa, Tokushima, Japan.

Submission: 笽July 06, 2019

Published: 留July 15, 2019

Volume 1 - Issue 5

How to cite this article: Akinori Nakanishi, Hiroshi Bando. Development of Health Resort Casino System in Integrative Medicine. Int J Conf Proc.1(5). ICP.000521.2019.

Copyright@ Hiroshi Bando, This article is distributed under the terms of the Creative Commons Attribution 4.0 International License, which permits unrestricted use and redistribution provided that the original author and source are credited.

\author{
Akinori Nakanishi ${ }^{1,2}$ and Hiroshi Bando ${ }^{2,3 *}$ \\ ${ }^{1}$ Clinic Shara, Tokushima, Japan \\ ${ }^{2}$ Shikoku Division of Integrative Medicine Japan (IMJ), Japan \\ ${ }^{3}$ Medical Research, Tokushima, Japan
}

\section{Abstract}

Keywords: Integrative Medicine Japan; Health resort casino system; Spa therapy; Casino health recuperation academy Japan (CHRAJ)

Abbreviation: Integrative Medicine (IM); Complementary and Alternative Medicine (CAM); Integrative Medicine Japan (IMJ); National Center for Complementary and Integral Health (NCCIH)

\section{Commentary}

From a historical point of view, Integrative Medicine (IM) adds Complementary and Alternative Medicine (CAM) to traditional Western Medicine (WM) and is considered to encompass the whole [1]. Period IM has been developed in various ways around the world [2]. There is a trend for application of CAM to many adults [3].

Recently, there has been a trend towards emphasizing evidence. There was a necessity to improve the rigor and transparency of systematic reviews published within BMC journal. Then, an affiliation between BMC CAM and Cochrane complementary medicine was established in recent years [4]. On the other hand, the National Center for Complementary and Integral Health (NCCIH) in United States always shows the appropriate information of IM and CAM [5].

In Japan, its importance has been recognized in recent years, and the Integrative Medicine Japan (IMJ) has branches throughout the country. The author Bando has been the chairman of Shikoku island division of IMJ and engaged in various activities [6]. Among them, the author Nakanishi has been continuing integrated medical care including spa therapy and various treatments centering on psychiatry. Just 30 years ago, in the area of integrated medicine, I had an opportunity to visit a hot spring treatment and related health care, an excellent site combining physical and mental treatment. Having experienced the episode, various activities have started, and various histories have begun to move. This paper describes these developments.

It was in Baden-Baden, Germany, that the author could see the activity on spa therapy in sight [7]. This city has long been known as one of Europe's leading spa resorts. First of all, the word (Baden) itself means "bathing", and the place name "Baden" came from there. In the $19^{\text {th }}$ century, with the development of transportation networks such as railways, many tourists came to visit [8]. The celebrities are often reunited here, and the musicians include Johannes Brahms and Johann Strauss. Also, Robert Koch (1843-1910), who discovered Anthrax, Mycobacterium tuberculosis, and cholera bacteria and received the Nobel prize for physiology and medicine, also passed away here.

Even now, the city is a spa resort known for its hot springs and the black forest [7]. Formerly known as the summer city of Europe, the city still has an elegant atmosphere. The whole city looks like a park, and Kurhaus (hot spring facilities) may also be cited as the oldest casino in Germany [8]. Many facilities are based on spa therapy but have a wide range of users. You can observe the actual and remember that you were surprised at its content and comfort, and the ratings of many users. Thus, spa therapy has been recognized as one of the recreational and 
healthy treatment in the recent tourism development [9]. Thermal springs can play a main role for growing recreational tourist with healthy and medical functions. As there are better care for health and better physical fitness and wealthier society, the standard quality of health resorts has been improved [10].

There have been lots of Kwahaus (care house) in Baden-Baden, Germany. Inside this building are the casino, the conference hall, the restaurant and the nightclub [7]. The casino tax rate is $80 \%$, $50 \%$ of which is used for:

\section{A. Expenditure for the state hot spring \\ B. Promotion of tourism \\ C. Protection of cultural property of the state \\ D. Maintenance of infrastructure \\ E. Other public purpose}

The landscape surrounding this building provides a sense of calm and security for visitors who have not changed for over 100 years $[8,9]$. As for spa therapy, there seems to be classified into 12 kinds [10]. Among them, resort/hotel spa, casino spa, medical spa (cosmetic), medical spa (wellness) and others. Concerning casino spa, it offers a chance to try their hand without leaving the premises. These properties can attract many travelers who want both of excitement and spa as they like [10]. Including spa therapy, there is wider category of the health tourism. They are thermal, spas, forest lodges, health spa resorts, herbal therapy, sauna, body repair food, theme parks, amusement parks, botanical gardens, shopping centers, casino visits and so on [11].

The simultaneous combined experience of casino and spa therapy was very impressed in my mind. After that in 2002, there was meaningful news about the possibility establishment of casino in the future in Japan. Consequently, the movement for making such a resort and/or hotel spa health spot were started, which is like that of Baden-Baden. The author established the "Casino Health Recuperation Academy Japan (CHRAJ)" in 2003 while investigating the political, social and economic possibility of future development [12]. Furthermore, we have continued to study with related parties in Japan such as integrated medicine, sightseeing, health care, health tourism and so on. Recently, there has been a discussion for Integrated Resort Law. Consequently, we have continued to develop and move into the "Naruto IR Health Recreation Invitational Conference" in the Tokushima area.

Firstly, the general situation for geopolitical characteristic of Tokushima would be described (Figure 1). It takes 2 hours by car from Osaka to Tokushima. There are world-famous scenic spots, cultural and tourist facilities at Naruto in 1.5-hour drive. In this area, there are several important spots, such as

A. One of the world's leading whirlpools (Whirlpool),

B. One of the largest suspension bridge "Large Naruto Bridge"(1629m in length, 144m in height),
C. International Otsuka Museum of Art;
D. The author's Clinic.

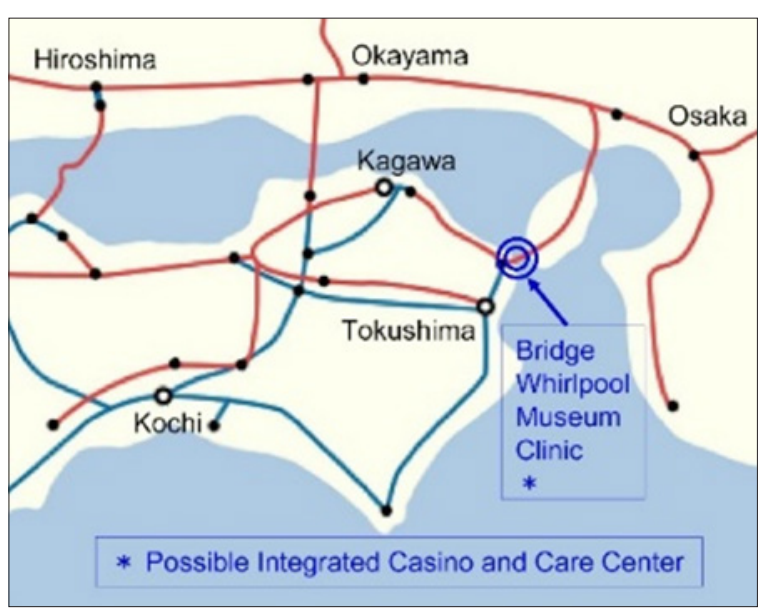

Figure 1: Map of Tokushima with possible health resort spot in the future.

Furthermore, there is a possibility due to several factors mentioned above. It is "the casino and health recreation center" can be made here with scenic sea and mountains (Figure 2). People can enjoy refreshing life apart from stressful daily life, and can experience forest bathing, recreation of village life and thalassotherapy [13].

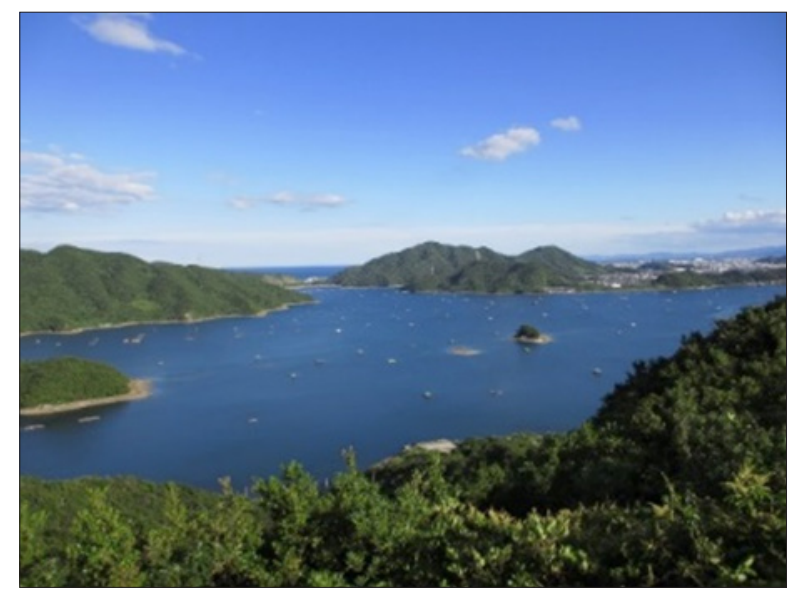

Figure 2: Beautiful scene of Naruto with possible integrated resort.

From these faculties with all related healthy elements, we can summarize them into" Health resort casino system". In more than 120 countries worldwide, the integrated resort law with casino has been valid for health resorts with visiting many people [14]. On the other hand, there has been continuing discussion as to proposed Integrated Resort Law in Japan. From healthier and happier life for people from childhood to centenarian, the adequate faculties of Health Recreation System would be expected in the future.

\section{References}

1. Micozzi MS (2018) Fundamentals of complementary, Alternative and Integrative Medicine. Elsevier, Missouri, USA, ISBN: 978-0-323-51081-3.

2. Chao MT, Adler SR (2018) Integrative medicine and the imperative for health justice. J Alternative Complementary Med 24(2): 1-3.

3. Clarke TC, Black LI, Stussman BJ, Barnes PM, Nahin RL (2015) Trends in the use of complementary health approaches among adults: United States, 2002-2012. Natl Health Stat Report 10(79): 1-16. 
4. Wieland LS, Pilkington K, Messin LJ (2019) Announcing the affiliation between BMC complementary and alternative medicine and cochrane complementary medicine. BMC Complement Altern Med 19: 69.

5. National Center for Complementary and Integrative Health (NCCIH).

6. Bando H, Yoshioka A, Nishikiori Y (2019) Music therapy in the hospital to heal patients for training of speech and swallow function. Int J Case Rep Clin Image 1(2): 107.

7. Sanner B (2000) Baden-Baden: A famous thermal spa with a long history. Geo-Heat Center (GHC) Bulletin.

8. Van TA, Vander Linden S (2002) A brief history of spa therapy. Ann Rheum Dis 61(3): 273-275.

9. Tretiakova TN, Shmeleva T, Brankov J (2018) Thermal springs and health tourism-the analysis of the meteorological parameters. J Geogr Inst Cvijic 68(1): 133-148.
10. Tang IF, Grace CSH, Tan CT, Leung RW (2018) Understanding generation y's favorite spa scent, spa food versus spa service experience. J Tourism Hospit 7: 374 .

11. Han JS, Lee TJ, Ryu K (2018) The promotion of health tourism products for domestic tourists. Int J Tourism Res 20(2): 137-146.

12. Casino Health Recuperation Academy Japan (CHRAJ).

13. Walton JK (2012) Health, sociability, politics and culture. Spas in history, spas and history: an overview. Journal of Tourism History 4(1): 1-14.

14. Węcławowicz E, Vaščak M (2018) Contemporary transformation of traditional polish health resorts against the background of changes observed in balneological centers around the world. Technical Transactions 11: 71-86. 